\title{
Key legislator collides with US officials on backing for CERN
}

[WASHINGTON] US plans to contribute half a billion dollars to the proposed Large Hadron Collider (LHC) at the European Laboratory for Particle Physics (CERN) in Switzerland have come under fire from the head of a key congressional committee, who claims that they take insufficient account of US interests.

Specific demands being made by James Sensenbrenner (Republican, Wisconsin), chair of the Science committee in the House of Representatives, include an assurance that US scientists will continue to enjoy free access to CERN, and a clear statement from European governments that, if a large accelerator is built in the future in the United States, they will help to pay for it.

He wants changes in a preliminary agreement reached earlier this year by CERN and the US Department of Energy (DoE), and says that US contributions will not be released until the agreement is modified.

Sensenbrenner has just returned from a private visit to CERN. Explaining his stance to a meeting of the American Association for the Advancement of Science (AAAS) in Washington DC last week, he said that he wants to see contingencies made for any cost overruns in the construction of the LHC.

$\mathrm{He}$ also expressed concern about what he said was the lack of a formal role for the United States in managing the project, and about the impact of the proposed US contribution on existing high-energy physics facilities in the United States.

Sensenbrenner also presented his concerns directly to Federico Peña, the new energy secretary. Peña said after the meeting that the concerns were "reasonable", and that some of them were, "frankly, concerns of mine too".

According to Peña, the DoE is already discussing such issues with CERN. He said that this would "not necessarily" involve renegotiating an agreement in a way that would require endorsement by the full CERN council.

But issues such as the management of the LHC project and contingency funding may be difficult to address without such a renegotiation. Last month, Martha Krebs, the assistant energy secretary who negotiated the preliminary agreement for the US side before Peña's arrival at the department, said that although the deal could still be open to "technical amendments", this would

\section{House limits reform to patent laws}

[WASHINGTON] Legislation designed to overhaul the US patent system, bringing it more into line with international practice, passed the House of Representatives last week, but only after last-minute amendments weakened several key reforms.

The bill, designated HR 400 and sponsored by Howard Coble (Republican, North Carolina), converts the Patent and Trademark Office from a federal agency into a government-owned corporation financed by patent fees. It also requires that patent applications be published 18 months after being filed, as is the practice in Europe and Japan. At present, US applications become public information only after a patent is granted, usually 20 to 22 months after filing.

The 18-month rule is intended to reduce the surprise element in the award of patents, and force the early publication of novel ideas. But small businesses, individual inventors and universities will be exempt, thanks to an amendment sponsored by Marcy Kaptur (Democrat, Ohio).

Two other clauses had been of particular concern to universities. One would have allowed the challengers of a patent to participate fully in the 're-examination' process. Critics claim that this would have favoured wealthy companies over small patent holders.

The second was a clause allowing those who had been making prior commercial use of an idea to continue using it even after a patent is granted to someone else. Some in the research community fear that this condition would make it more difficult for universities to grant exclusive licences for their inventions, which have become an important source of revenue.

The re-examination clause was cut out by an amendment approved during the debate on the floor of the House last week. The allowance for 'prior use' was restricted to satisfy the university community and other opponents of the original bill.

A disappointed Coble said these and other changes to his legislation have weakened it, but "the damage is not irreparable". A similar bill, S 507, which is sponsored by Orrin Hatch (Republican, Utah), is now moving through the Senate. Representatives of the university community say that they are planning to monitor its progress closely. Tony Reichhardt See Commentary, page 13.

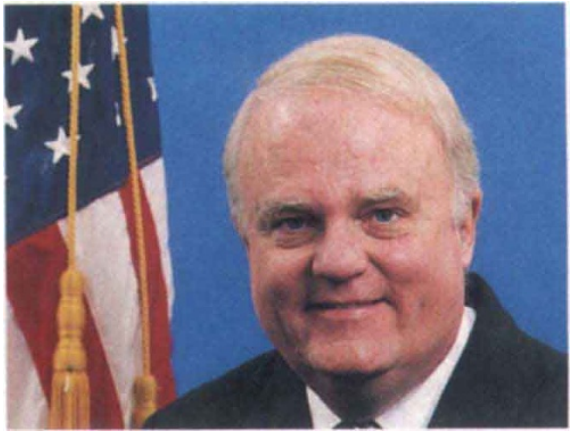

Sensenbrenner: Threatens to block funds until preliminary agreement is modified.

involve "nothing substantive".

Christopher Llewellyn Smith, the director-general of CERN, says Sensenbrenner was "doing his job" by scrutinizing the agreement closely. "He's asking good questions, but I think the answers are all there in the agreement." Llewellyn Smith says that an article in the agreement already guarantees open access to the LHC for US scientists. He said that costs are under firm control, and that the European members of CERN would be responsible for any overruns. "The US contribution is fixed," he says.

Llewellyn Smith adds that any assurances on support for future US projects could come only from European governments, not from CERN itself. He also says that any substantial modifications to the agreement would have to go back to the CERN council, which next meets in June, for ratification. "The deal can be changed, but we consider it to be satisfactory for all parties," he says.

As an authorization committee, the House Science committee has only limited power over budget matters. But, for political and technical reasons, it is highly unlikely that the appropriations subcommittees, which have the budgetary power, will fund a major new science project without the Science committee's support. This is especially true of LHC, which has hardly any constituency outside the science community.

Sensenbrenner's stance means that \$35 million that the Clinton administration had planned to spend on the LHC in the next financial year, beginning on 1 October, remains excluded from an advisory budget bill passed by his committee two weeks ago (see Nature 386, 748; 1997).

Officials at Fermilab and Brookhaven National Laboratory, where most of the money would be spent, are increasingly concerned that this money may remain excluded from the budget. They had hoped Sensenbrenner would return from CERN satisfied, and would amend the committee's proposal 
before it reached the floor of the House.

But Sensenbrenner now says its "up to secretary Peña" to meet his demands and get the money restored. The bill is expected to reach the House floor later this month. According to congressional staff and laboratory officials, supporters of the LHC are worried that an attempt to restore the funds on the floor of the House could well be defeated. "Everyone knows that if you take this to the floor, you lose," says one.

Sensenbrenner's staff say that he supports US participation in the LHC, but wants a better deal that will survive future attacks in Congress. "There are good deals and bad deals - Martha Krebs' deal is a bad one that has to be changed," Sensenbrenner says.

Nevertheless, his recent public statements have been short on praise for the LHC, and have reflected some of the views of Joe Barton (Republican, Texas) the project's fiercest congressional critic (see Nature 386, 97; 1997).

Sensenbrenner told last week's AAAS meeting that, while he was "all for" international collaboration in science, the Superconducting Super Collider (SSC) had failed because it had not attracted international contributions, particularly from Europe.

"Carlo Rubbia, the [then] director of CERN, waved his finger at the United States and actively lobbied against European support for SSC," Sensenbrenner argued. A European pledge to help with a future US machine would "put an end to Rubbia-ism in Geneva", he suggested.

Whatever happens next, Sensenbrenner's attack on the initial deal between the DoE and CERN marks the unravelling of the Clinton administration's strategy of pushing through, with minimal fuss, the largest-ever US investment in an overseas science project. Costs would involve $\$ 450$ million from the $\mathrm{DoE}$ and probably another $\$ 80$ million from the National Science Foundation.

Three years ago, a panel chaired by Sidney Drell, deputy director of the Stanford Linear Accelerator Center in California, suggested that the United States should participate in the project. But it warned that it would need the explicit endorsement of President Clinton to succeed (see Nature 369, 266; 1994).

Since then, however, Krebs' Office of Energy Research has pursued the agreement on its own, with little public backing from Hazel O'Leary, the former energy secretary, or other senior members of the administration. Last week, the new energy secretary sought to correct this, speaking out in favour of the project at the AAAS meeting.

"We are requesting funds to participate in the construction of the next major high energy physics research facility in the world the LHC," Peña said. "Successful international collaboration is important to the future of these large scientific facilities; we must succeed on this one."

Colin Macilwain

\section{Spaceflight monkey's death 'raises new safety issues'}

[WASHINGTON] US space researchers have dropped plans to fly rhesus monkeys on the Russian Bion 12 spacecraft next year. Their decision follows the conclusions of a review panel that the animals face a previously unsuspected risk of death on their return to Earth.

The panel was set up after one of the two monkeys that were used on the 14-day Bion 11 mission last December died unexpectedly under anaesthesia during a routine biopsy conducted the day after landing (see Nature 385, 289;1997). The mission was one of a series designed to test the effects of weightlessness and space radiation on living organisms.

The decision brings to an abrupt end a long-running controversy about whether the National Aeronautics and Space Administration (NASA) should fly monkeys on the Bion missions. The December mission, for which NASA had followed the advice of several scientific review panels, had encountered protests from animal rights groups. There have also been attempts to kill the programme in Congress. Indeed, Tim Roemer (Democrat, Indiana), a member of the House of Representatives Science committee, had begun circulating a "Dear Colleague" letter headlined "Get the monkey off the taxpayer's back!", the day before NASA's decision.

Alice Hellerstein, a spokeswoman for the American Physiological Society, which had backed the Bion experiments during congressional debates last year, says " $\mathrm{t}] \mathrm{he}$ timing is unfortunate, because it looks like they were pressured politically". However, she believes that, despite the possible embarrassment to NASA, the agency made a "tough but honest" decision based on new scientific evidence.

Ronald Merrell, chairman of Yale University's department of surgery and head of the panel that reviewed the Bion research protocols both before and after the flight, says that as well as being a genuine surprise, the result is of considerable scientific interest.

Russian researchers had previously conducted 10 successful biopsies on monkeys after long space-flights, following procedures used routinely in laboratories on Earth. But they had never anaesthetized an animal so soon after its return from space.

According to NASA's chief veterinarian, Joseph Bielitzki, the soonest it had been done previously was seven days after landing. But the Bion 11 experiment required that tissue be taken immediately from the monkeys in order to investigate the body's transition from weightlessness to gravity.
Merrell says that physiological changes that occur in space appear to have reduced the monkey's ability to tolerate the stress of anaesthesia. The review panel therefore concluded that continuing with the same experimental protocol for Bion 12 posed an additional risk to the test subjects.

The panel did not tell NASA to scrap the project, says Merrell. But, in the light of the new findings, the agency faced a choice between risking the death of the Bion 12 monkeys - which would have inflamed political opponents - or waiting several days after landing before taking biopsy tissue, which would reduce its value.

NASA headquarters chose to cut its losses after what Bielitzki describes as "a lot of discussion", reaching as high as Daniel Goldin, NASA's administrator. According to Bielitz$\mathrm{ki}$, there is "a significant amount of disappointment" among Bion 12 researchers.

The rhesus monkeys were originally to have flown on a US Spacelab mission last year, but were switched to Bion when that flight was cancelled. The experiment had been approved by four scientific review panels since 1988, including one convened by the American Institute of Biological Sciences. But the plan to anaesthetize the monkeys immediately after landing never emerged as a significant worry. "Hindsight is always 20-20," says Bielitzki.

Other US animal experiments will still fly on Bion 12, along with investigations sponsored by Russian and French researchers. And, ironically, the death of the Bion 11 monkey may leave an important scientific legacy. NASA may want to reconsider whether or not to operate immediately on astronauts who return from space in an emergency. "[Agency doctors] are probably thinking about this right now," says Merrell.

Tony Reichhardt

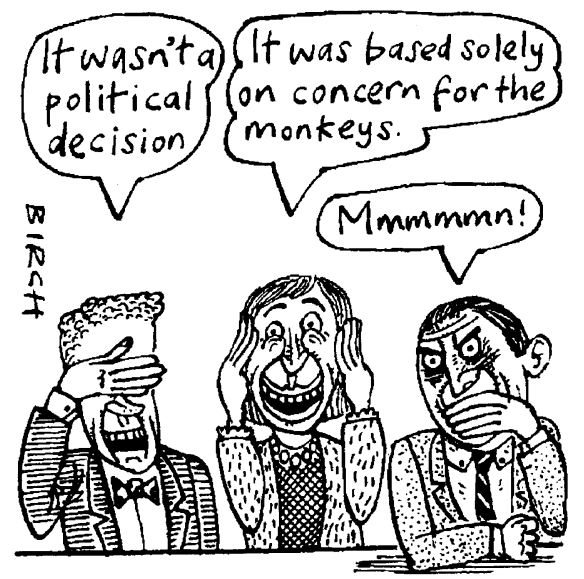

THE THREE WISE NASA OFFICIALS 